\title{
High quality draft genome sequence of the heavy metal resistant bacterium Halomonas zincidurans type strain $\mathrm{B}^{\top}$
}

\author{
Ying-Yi Huo ${ }^{1}$, Zheng-Yang Li ${ }^{1}$, Hong Cheng ${ }^{2}$, Chun-Sheng Wang ${ }^{1}$ and Xue-Wei Xu ${ }^{1 *}$
}

\begin{abstract}
Halomonas zincidurans strain $\mathrm{B}^{\top}{ }^{\top}$ was isolated from a deep-sea heavy metal rich sediment from the South Atlantic Mid-Ocean Ridge. The strain showed significant resistance to heavy metals, especially to zinc. Here we describe the genome sequence and annotation, as well as the features, of the organism. The genome contains 3,325 protein-coding genes (2,848 with predicted functions), 61 tRNA genes and 6 rRNA genes. H. zincidurans strain B6 ${ }^{\top}$ encodes 31 genes related to heavy metal resistance. And HGT may play an important role in its adaption to the heavy metal rich environment. $H$. zincidurans strain $\mathrm{B}^{\top}$ may have potential applications in the bioremediation of heavy metal-contaminated environments.
\end{abstract}

Keywords: Halomonas, Heavy metal resistant, The South Atlantic Ocean, Genome

\section{Introduction}

Heavy metals, either essential (e.g. $\mathrm{Mn}, \mathrm{Zn}, \mathrm{Cu}, \mathrm{Co}, \mathrm{Ni}$ and $\mathrm{Mo}$ ) or toxic (e.g. $\mathrm{Hg}, \mathrm{Ag}$ and $\mathrm{Cd}$ ), are generally harmful to microbial cells even at low concentrations, as to other living organisms [1,2]. However, some microorganisms are able to resist to certain kinds and concentrations of heavy metals through several mechanisms, such as incorporating or precipitating heavy metals into complexes, oxidizing or reducing metals to less toxic valence states, and direct transporting metals out of the cell $[3,4]$. These heavy metal resistant microorganisms have been attracting great interests because of their potential biotechnological applications in bio-mining of expensive heavy metals and bioremediation of heavy metal-contaminated environment [2].

Halomonas, the largest genus of the family Halomonadaceae, can be found in most saline environments, including marine environments, salterns, saline lakes and soils, as well as salty foods, etc. [5,6]. Halomonas zincidurans strain $\mathrm{B}^{\mathrm{T}}$, a moderately halophilic bacterium, was isolated from a deep-sea sediment from the South Atlantic

\footnotetext{
*Correspondence: xuxw@sio.org.cn

'Laboratory of Marine Ecosystem and Biogeochemistry, Second Institute of Oceanography, State Oceanic Administration, Hangzhou, P. R. China

Full list of author information is available at the end of the article
}

Mid-Ocean Ridge [5]. The strain was able to grow in medium containing high concentrations of heavy metals, especially $\mathrm{Zn}^{2+}$ ion, which is not detected in the reference strains and other moderately halophiles [5,7]. Therefore, the novel isolate was named as $H$. zincidurans due to its particular resistance to zinc ion [5]. Here, we present a summary classification and a set of features of $H$. zincidurans strain $\mathrm{B}^{\mathrm{T}}$, together with the description of the genomic sequencing and annotation.

\section{Organism information}

A deep-sea sediment sample, TVG10, was collected from the South Atlantic Mid-Ocean Ridge (Table 1). There were many small hard orange red-colored lumps mixed in the sediment sample, which might be the particles containing ferric oxide and diffusing with hydrothermal plumes [8]. Not surprisingly, the concentrations of heavy metals in sample TVG10 were much higher than those in the samples collected from deep-sea seamount sediment [9], offshore sediment [10] and continental crust [11] (Additional file 1: Table S1), including Fe (98.99 mg/g), Mn (42.48 mg/g), $\mathrm{Cu}(0.839 \mathrm{mg} / \mathrm{g}), \mathrm{Ni}(0.338 \mathrm{mg} / \mathrm{g}), \mathrm{Zn}(0.285 \mathrm{mg} / \mathrm{g})$, Cr $(0.195 \mathrm{mg} / \mathrm{g})$ and Co $(0.064 \mathrm{mg} / \mathrm{g})$. With consideration of the heavy metal rich environment, marine broth 
Table 1 Classification and general features of $H$. zincidurans $\mathrm{B}^{\mathrm{T}}{ }^{\mathrm{accordin}}$ to the MIGS recommendations [12]

\begin{tabular}{|c|c|c|c|}
\hline MIGS ID & Property & Term & $\begin{array}{l}\text { Evidence } \\
\text { code }^{\mathrm{a}}\end{array}$ \\
\hline & \multirow[t]{8}{*}{ Current classification } & Domain Bacteria & TAS [13] \\
\hline & & Phylum Proteobacteria & TAS [14] \\
\hline & & Class Gammaproteobacteria & TAS $[15,16]$ \\
\hline & & Order Oceanospirillales & TAS $[15,17]$ \\
\hline & & Family Halomonadaceae & TAS [18-22] \\
\hline & & Genus Halomonas & TAS $[22-24]$ \\
\hline & & Species Halomonas zincidurans & TAS [5] \\
\hline & & Type strain $B 6^{\top}=$ CGMCC $1.12450^{\top}=J C M 18472^{\top}$ & \\
\hline & Gram stain & Negative & TAS [5] \\
\hline & Cell shape & Rod & TAS [5] \\
\hline & Motility & Motile & TAS [5] \\
\hline & Sporulation & Nonsporulating & TAS [5] \\
\hline & Temperature range & $4-37^{\circ} \mathrm{C}$ & TAS [5] \\
\hline & Optimum temperature & $35^{\circ} \mathrm{C}$ & TAS [5] \\
\hline & pH range; Optimum & $5.0-8.5 ; 7.0$ & \\
\hline & Carbon source & $\begin{array}{l}\text { Adonitol, L-arabinose, cellobiose, ethanol, D-fructose, D-glucose, glycerol, maltose, mannitol, } \\
\text { D-mannose, D-ribose, D-salicin, D-sorbitol, starch, D-xylose, acetate, citrate, D-gluconate, propionate, } \\
\text { pyruvate, succinate, L-alanine, L-arginine, glycine, L-glutamate, L-lysine, L-ornithine and L-serine }\end{array}$ & TAS [5] \\
\hline MIGS-6 & Habitat & Deep-sea sediment & TAS [5] \\
\hline MIGS-6.3 & Salinity & Moderately halophilic, $0.5-15 \% \mathrm{NaCl}$ & TAS [5] \\
\hline MIGS-22 & Oxygen & Strictly aerobic & TAS [5] \\
\hline MIGS-15 & Biotic relationship & Free-living & NAS \\
\hline MIGS-14 & Pathogenicity & Not reported & \\
\hline MIGS-4 & Geographic location & South Atlantic Ocean & TAS [5] \\
\hline MIGS-5 & Sample collection time & Feb 20, 2012 & NAS \\
\hline MIGS-4.1 & Latitude & $13.60^{\circ} \mathrm{S}$ & TAS [5] \\
\hline MIGS-4.2 & Longitude & $14.52^{\circ} \mathrm{W}$ & TAS [5] \\
\hline MIGS-4.3 & Depth & $2950 \mathrm{~m}$ & TAS [5] \\
\hline MIGS-4.4 & Altitude & $-2950 m$ & TAS [5] \\
\hline
\end{tabular}

Evidence codes - TAS: Traceable Author Statement (i.e., a direct report exists in the literature); NAS: Non-traceable Author Statement (i.e., not directly observed for the living, isolated sample, but based on a generally accepted property for the species, or anecdotal evidence). These evidence codes are from the Gene Ontology project [25].

2216 medium (MB, BD) containing $20 \mathrm{mM} \mathrm{Mn}^{2+}$ was used to isolate heavy metal resistant strains. Subsequently a strain named $\mathrm{B}^{\mathrm{T}}$ was obtained [5].

H. zincidurans strain $\mathrm{B}^{\mathrm{T}}$ is a Gram-stained negative, rod-shaped (Figure 1), moderately halophilic bacterium growing at $0.5-15 \%(\mathrm{w} / \mathrm{v}) \mathrm{NaCl}$ (Table 1). Strain $\mathrm{B6}^{\mathrm{T}}$ exhibited the highest $16 \mathrm{~S}$ rRNA gene sequence similarity with $H$. xinjiangensis (96.1\%). Phylogenetic analysis based on 16S rRNA gene sequences showed that strain $\mathrm{B}^{\mathrm{T}}$ and $H$. xinjiangensis clustered together in a distinct branch within the genus Halomonas with a high bootstrap value (Figure 2). Strain $\mathrm{B}^{\mathrm{T}}$ was able to resist high concentrations of heavy metals in liquid HM medium, including $\mathrm{Mn}^{2+}(200 \mathrm{mM}), \mathrm{Co}^{2+}(1.0 \mathrm{mM}), \mathrm{Cu}^{2+}(2.5 \mathrm{mM})$ and $\mathrm{Zn}^{2+}(14 \mathrm{mM})$. Its resistance to $\mathrm{Zn}^{2+}$ could be much higher $(30 \mathrm{mM})$ when incubated on marine agar 2216 medium (MA, BD) [5], comparing to only $1 \mathrm{mM} \mathrm{Zn}^{2+}$ resisted by $H$. xinjiangensis TRM0175 ${ }^{\mathrm{T}}$. And the maximum zinc resistance concentration for 250 moderately halophilic bacteria, reported by Nieto et al., was only $2.5 \mathrm{mM}$ [7]. Therefore, H. zincidurans strain $\mathrm{B}^{\mathrm{T}}$ is of significant interest due to its prominent resistance to zinc.

\section{Genome sequencing information}

Genome project history

The next-generation shotgun-sequencing and quality assurance was performed at the Beijing Genome Institute 


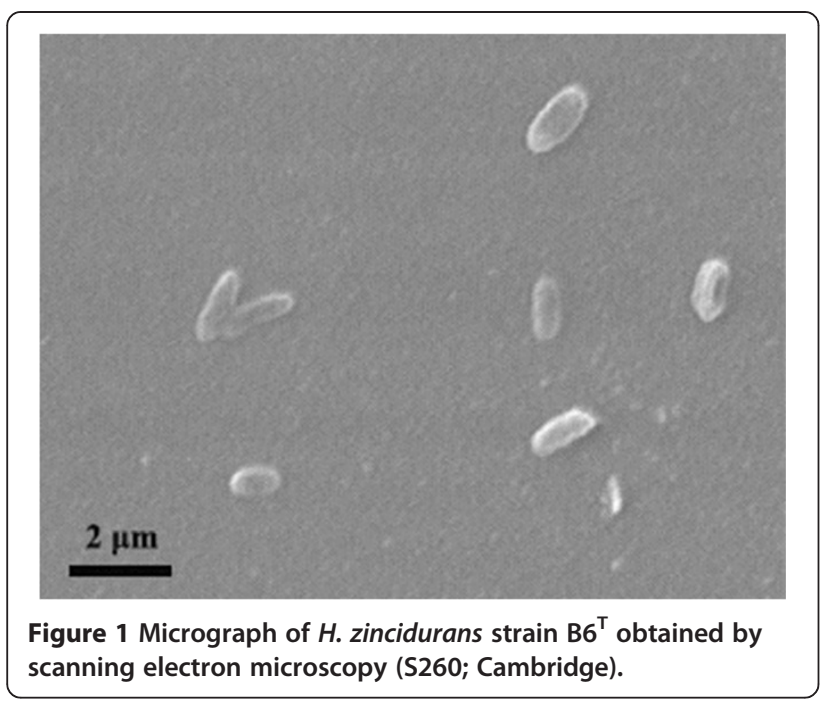

(BGI, Shenzhen). The gap closure and annotation processes were performed by the authors. The Whole Genome Shotgun project of $H$. zincidurans strain $\mathrm{B}^{\mathrm{T}}$ has been deposited at DDBJ/EMBL/GenBank under the accession JNCK00000000. The version described in this paper is version JNCK01000000. Table 2 presents the project information and its association with MIGS version 2.0 compliance [12].

\section{Growth conditions and DNA isolation}

H. zincidurans strain $\mathrm{B}^{\mathrm{T}}$ was aerobically cultivated in $\mathrm{MB}$ medium at $30^{\circ} \mathrm{C}$. Total genomic DNA was extracted using the method described by Marmur [32]. The quality and quantity of the genomic DNA was determined by $0.6 \%$ agarose gel electrophoresis with $\lambda$-Hind III digest DNA marker (TaKaRa, Dalian, China) and by a Qubit $^{\circ}$ fluorometer (Invitrogen, CA, USA) with Qubit dsDNA BR Assay kit (Invitrogen, CA, USA). About $350 \mu \mathrm{g}$ DNA with a concentration of $450 \mathrm{ng} / \mu \mathrm{l}$ was obtained.

\section{Genome sequencing and assembly}

Whole-genome shotgun DNA sequencing of $H$. zincidurans strain $\mathrm{B}^{\mathrm{T}}$ was performed using Solexa pairedend sequencing technology (HiSeq2000 system, Illumina, USA) [33]. Two libraries with insert size $494 \mathrm{bp}$ and 2,586 bp were constructed and a total of $519 \mathrm{Mb}$ and $416 \mathrm{Mb}$ raw data were produced before filtering. After removing the adapter, duplicated reads and short inserts from the data of large library, there remained $433 \mathrm{Mb}(\sim 120$-folds genome coverage) and $328 \mathrm{Mb}(\sim 90-$ folds genome coverage) clean data from the small and large libraries for assembling, respectively. Then these sequences were assembled into 15 contigs using the SOAPdenovo v.1.05 [30], the contig N50 length of which was 1,864,365 bp. PCR primers for gap closure were designed by Primer Premier v.5. PCR reactions were performed with PrimeSTAR HS Polymerase (TaKaRa, Dalian, China) and the amplicons were sequenced using Sanger and primer walking technologies. The sequenced fragments were subsequently assembled with the contigs using SeqMan of the Lasergene package (DNAstar, Madison, WI) into 2 contigs.

\section{Genome annotation}

The whole genomic tRNAs were identified using tRNAscanSE v.1.21 [34] with bacterial model, and rRNAs were found by RNAmmer v.1.2 Server [35]. ORFs were predicted using Glimmer v.3.0 [31]. The predicted ORFs were translated and analyzed using the NCBI nonredundant, Swiss-Prot [36] and COG [37] databases, as well as RAST server online [38] for genome annotation. KAAS [39] was used to assign the predict proteins into KEGG pathway [40] with BBH method. Genes with signal peptides and transmembrane helices were predicted using TMHMM server v.2.0 [41] and SignalP server v.4.1 [42], respectively. The $\mathrm{G}+\mathrm{C}$ content, $\mathrm{G}+\mathrm{C}$ content at the third-codon position and RSCU were calculated by CodonW v.1.4.4.

\section{Genome properties}

The genome was assembled into 2 contigs, one with a size of 3,546,937 bp and the other with 7,823 bp (Table 3). The $\mathrm{G}+\mathrm{C}$ content determined based on the total $3,554,760 \mathrm{bp}$ sequences was $66.41 \%$. A total of 3,392 genes were predicted, including 3,325 proteincoding genes, 61 tRNA genes and two copies of 16S23S-5S rRNA gene operons (Table 4 and Figure 2). Among the protein coding genes, 2,848 were assigned to putative functions, and the remaining was annotated as hypothetical proteins. In total, 1,938 and 442 protein coding genes were assigned to KEGG and subsystems, respectively. The detailed properties and the statistics of the genome as well as the distribution of genes into COG functional categories are summarized in Tables 3, 4 and 5, Figure 3 and Additional file 2: Table S2.

\section{Insights into the genome}

The genome of $H$. zincidurans strain $\mathrm{B}^{\mathrm{T}}$ contains 31 genes related to heavy metal resistance, especially to zinc resistance (Table 6). Zinc is an essential but also toxic metal for living being $[2,43]$. The concentration of zinc inside bacterial cells is maintained by importing limitation, efflux, accumulation and sequestration [44,45]. H. zincidurans strain $\mathrm{B} 6^{\mathrm{T}}$ possesses four heavy metal translocating P-type ATPases (HALZIN_733, HALZIN_1240, HALZIN_ 2196 and HALZIN_2262), which may participate in the transport of $\mathrm{Zn}^{2+}, \mathrm{Mn}^{2+}, \mathrm{Cu}^{2+}, \mathrm{Cd}^{2+}, \mathrm{Pb}^{2+}, \mathrm{Ag}+$ and $\mathrm{Hg}^{2+}$ 


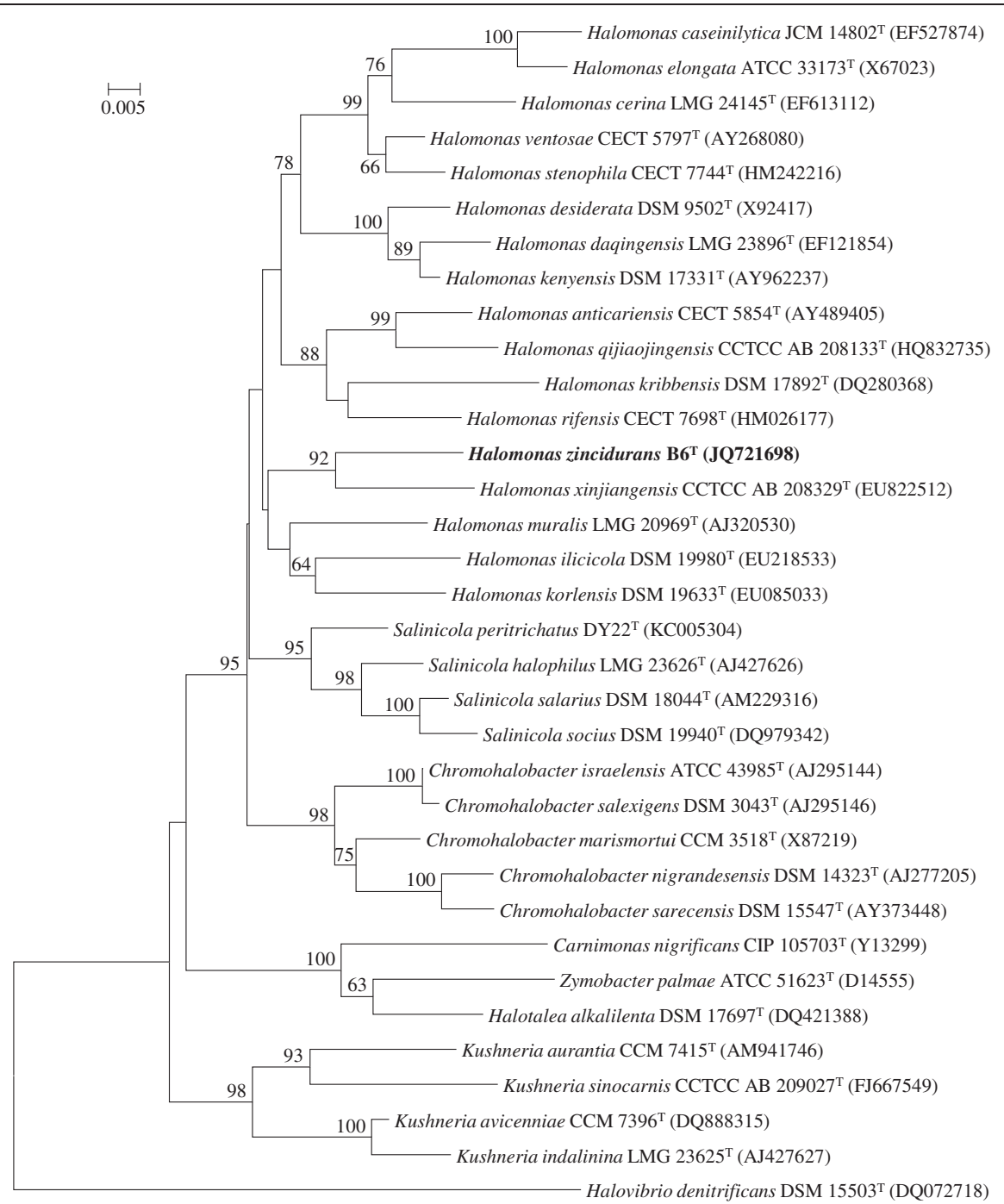

Figure 2 Phylogenetic tree highlighting the position of $H$. zincidurans strain $B 6^{\top}$ relative to phylogenetically closely related type strains within the family Halomonadaceae. The sequences were aligned using Clustal W [26], and the neighbor-joining tree [27] was constructed based on kimura 2-parameter distance model [28] by using MEGA5 [29]. Bootstrap values above 60\% are shown obtained from 1,000 bootstrap replications. Bar, 0.05 substitutions per nucleotide position. The corresponding GenBank accession numbers are displayed in parentheses.

against the concentration gradient to the periplasm [2,44]. Especially the two ZntA P-type ATPases (HALZIN_733 and HALZIN_2196) may mediate resistance to $\mathrm{Zn}^{2+}, \mathrm{Cd}^{2+}$ and $\mathrm{Pb}^{2+}[46,47] \cdot \mathrm{Zn}^{2+}, \mathrm{Co}^{2+}, \mathrm{Cu}^{2+}, \mathrm{Cd}^{2+}$ and $\mathrm{Ni}^{2+}$ are able to be transported by RND family efflux transporter protein (HALZIN_54, HALZIN_1411, HALZIN_2047, HALZIN_2208 and HALZIN_2209) from both the cytoplasm and the periplasm to outside $[2,44]$. Usually the P-type ATPases are regulated by MerR family regulators responding to the intracellular heavy metal concentration $[44,48,49]$. Six analogues of MerR family regulators (HALZIN_399, HALZIN_922, HALZIN_2261, HALZIN_ 2264, HALZIN_2469 and HALZIN_2675) were found in the genome of $H$. zincidurans strain $\mathrm{B}^{\mathrm{T}}$. Additionally, a zinc uptake regulation protein ZUR (HALZIN_1413), which is a repressor regulator during zinc uptake, is also detected $[44,50]$. The presence of these genes is accordance with zinc resistance phenotype of $\mathrm{H}$. zincidurans strain $\mathrm{B}^{\mathrm{T}}$.

Among the 31 ORFs related to heavy metal resistance, it is noteworthy of two mer-operons. One mer-operon encodes a mercuric transport protein (MerE, HALZIN_916) for organic mercury uptake [51], a transcriptional regulator (MerD, HALZIN_917), three alkylmercury lyases (MerB, HALZIN_918-920) catalyzing organomercurials yielding $\mathrm{Hg}^{2+}$ [52] and a transcriptional regulator (MerR, 
Table 2 Project information

\begin{tabular}{|c|c|c|}
\hline MIGS ID & Property & Term \\
\hline MIGS-31 & Finishing quality & High-quality draft \\
\hline MIGS-28 & Libraries used & $\begin{array}{l}\text { One pair-end } 494 \text { bp library and } \\
\text { one pair-end 2,586 bp library }\end{array}$ \\
\hline MIGS-29 & Sequencing platforms & Illumina HiSeq 2000 \\
\hline MIGS-31.2 & Fold coverage & $\begin{array}{l}120 \times(494 \text { bp library }) \text { and } 90 \times \\
(2,586 \text { bp library })\end{array}$ \\
\hline MIGS-30 & Assemblers & SOAPdenovo [30] \\
\hline \multirow[t]{7}{*}{ MIGS-32 } & Gene calling method & Glimmer v3.02 [31] \\
\hline & Locus Tag & HALZIN \\
\hline & Genbank ID & JNCK00000000 \\
\hline & Genbank Date of Release & July 21, 2014 \\
\hline & GOLD ID & Gi0069861 \\
\hline & BIOPROJECT & PRJNA234075 \\
\hline & Project relevance & $\begin{array}{l}\text { Type strain, environmental, } \\
\text { heavy metal resistance }\end{array}$ \\
\hline MIGS-13 & Source Material Identifier & CGMCC 1.12450, JCM 18472 \\
\hline
\end{tabular}

HALZIN_922). The other one encodes a transcriptional regulator (MerR, HALZIN_2469), two mercuric transport proteins (MerT and MerP, HALZIN_2470-2471) for inorganic mercury uptake [51] and a mercuric reductase (MerA, HALZIN_2472) catalyzing $\mathrm{Hg}^{2+}$ to $\mathrm{Hg}^{0}$ [53]. According to the genomic data, H. zincidurans strain $\mathrm{B}^{\mathrm{T}}$ is able to survive in both inorganic and organic mercury environments. Interestingly, the four ORFs of the inorganic mer-operon showed the highest sequence identities to those of Halomonas lutea. Nevertheless, all the six ORFs of the organic mer-operon did not show the highest sequence identities to those of the genus Halomonas, but to the genera Burkholderia, Pseudomonas, Gladiecola and Stenotrophomonas, which indicates that the organic mer-operon might be acquired by HGT. Of special interest are the three alkylmercury lyases (MerB, HALZIN_918-920), which had obvious differences between the $\mathrm{G}+\mathrm{C}$ content (56.6\%; 57.1, 56.6 and $56.0 \%$ for these three gene sequences, respectively) as well as the $\mathrm{G}+\mathrm{C}$ content at the third-codon positions $(60.3 \% ; 60.4,61.0$ and $59.4 \%$ for these three gene sequences, respectively) and those of the total proteincoding genes (65.4 and $82.8 \%$, respectively). Besides, the RSCUs of nearly half of the 59 codons used by the three genes (23, 27 and 26 codons for HALZIN_918-920, respectively) change more than 2 folds, compared with those used by total protein-coding genes. 13 of the 31

Table 3 Summary of genome: two contigs

\begin{tabular}{lccc}
\hline Label & Size $(\mathbf{M b})$ & Topology & INSDC identifier \\
\hline Contig 1 & 3.546937 & Linear & JNCK01000001.1 \\
Contig 2 & 0.007823 & Linear & JNCK01000002.1 \\
\hline
\end{tabular}

Table 4 Nucleotide content and gene count levels of the genome

\begin{tabular}{lrr}
\hline Attribute & \multicolumn{2}{c}{ Genome (total) } \\
\cline { 2 - 3 } & Value & \% of total \\
\hline Genome size (bp) & $3,554,760$ & - \\
DNA coding (bp) & $3,153,982$ & 88.73 \\
DNA G+C (bp) & $2,289,453$ & 66.41 \\
DNA scaffolds & 2 & - \\
Total genes & 3,392 & - \\
Protein coding genes & 3,325 & 98.02 \\
RNA genes & 67 & 1.98 \\
Genes with function prediction & 2,916 & 85.97 \\
Genes assigned to COGs & 2,764 & 81.49 \\
1 or more conserved domains & 2,764 & 81.49 \\
2 or more conserved domains & 329 & 9.70 \\
3 or more conserved domains & 74 & 2.18 \\
4 or more conserved domains & 23 & 0.68 \\
Genes with Pfam domains & 2,188 & 64.50 \\
Genes with signal peptides & 180 & 5.31 \\
Genes with transmembrane helices & 697 & 20.55 \\
CRISPR repeats & 1 & - \\
\hline
\end{tabular}

Table 5 Number of genes associated with the $\mathbf{2 5}$ general COG functional categories

\begin{tabular}{|c|c|c|c|}
\hline Code & Value & $\%$ of total & Description \\
\hline J & 164 & 5.14 & Translation \\
\hline A & 1 & 0.03 & RNA processing and modification \\
\hline K & 230 & 7.21 & Transcription \\
\hline$L$ & 188 & 5.89 & Replication, recombination and repair \\
\hline B & 4 & 0.13 & Chromatin structure and dynamics \\
\hline $\mathrm{D}$ & 32 & 1.00 & Cell cycle control, mitosis and meiosis \\
\hline Y & - & - & Nuclear structure \\
\hline V & 33 & 1.03 & Defense mechanisms \\
\hline $\mathrm{T}$ & 127 & 3.98 & Signal transduction mechanisms \\
\hline M & 182 & 5.71 & Cell wall/membrane biogenesis \\
\hline $\mathrm{N}$ & 64 & 2.01 & Cell motility \\
\hline Z & - & - & Cytoskeleton \\
\hline W & - & - & Extracellular structures \\
\hline$U$ & 62 & 1.94 & Intracellular trafficking and secretion \\
\hline $\mathrm{O}$ & 109 & 3.42 & $\begin{array}{l}\text { Posttranslational modification, protein } \\
\text { turnover, chaperones }\end{array}$ \\
\hline C & 215 & 6.74 & Energy production and conversion \\
\hline G & 216 & 6.77 & Carbohydrate transport and metabolism \\
\hline$E$ & 325 & 10.19 & Amino acid transport and metabolism \\
\hline $\mathrm{F}$ & 76 & 2.38 & Nucleotide transport and metabolism \\
\hline$H$ & 145 & 4.55 & Coenzyme transport and metabolism \\
\hline 1 & 118 & 3.70 & Lipid transport and metabolism \\
\hline $\mathrm{P}$ & 171 & 5.36 & Inorganic ion transport and metabolism \\
\hline Q & 108 & 3.39 & $\begin{array}{l}\text { Secondary metabolites biosynthesis, } \\
\text { transport and catabolism }\end{array}$ \\
\hline $\mathrm{R}$ & 391 & 12.26 & General function prediction only \\
\hline S & 229 & 7.18 & Function unknown \\
\hline- & 628 & 18.51 & Not in COGs \\
\hline
\end{tabular}




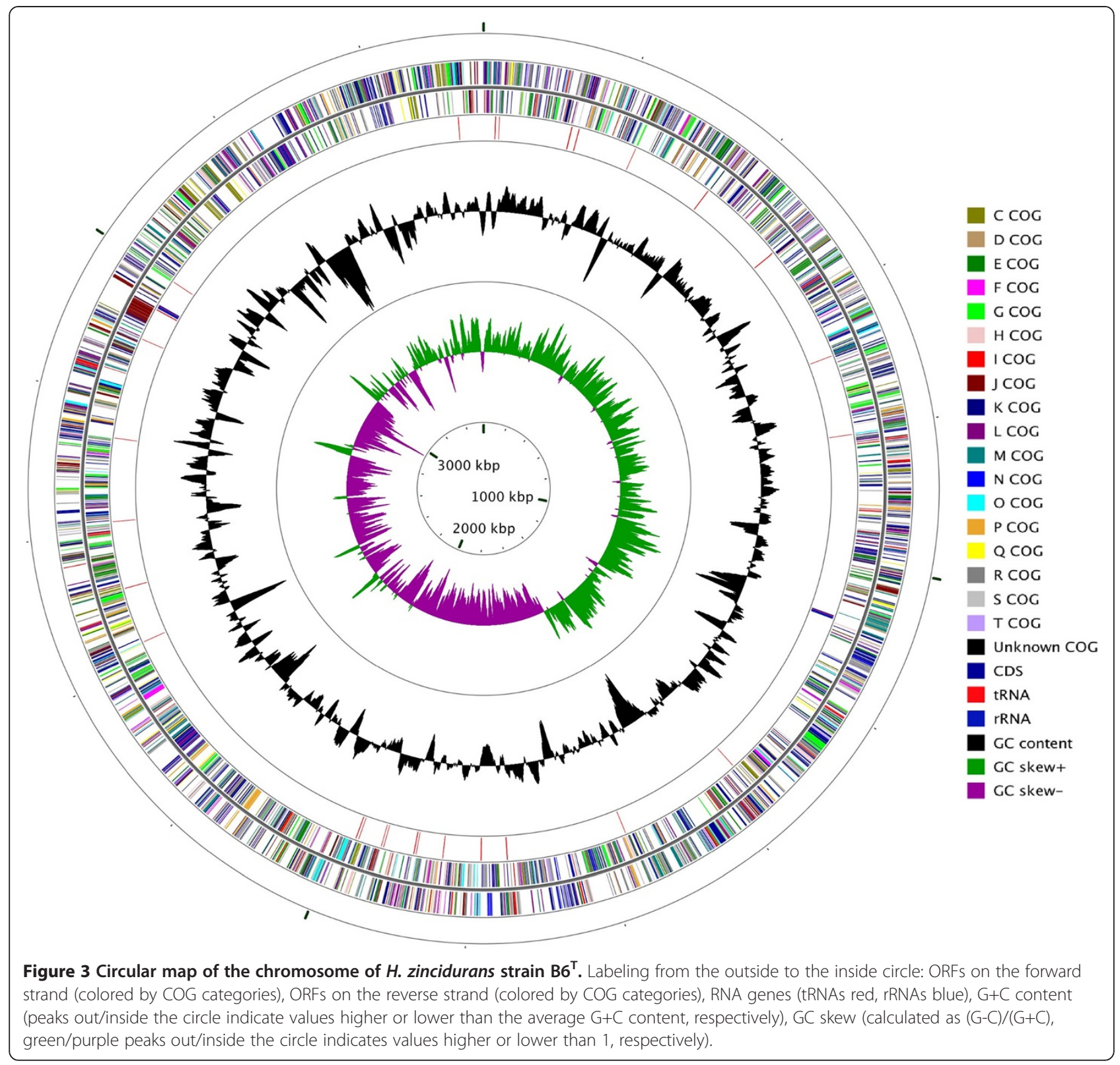

ORFs (41.9\%) were not related to Halomonadaceae genes according to the gene sequence similarity analysis, 9 of the 13 ORFs had RSCU change larger than 2 folds in more than $25 \%$ codons. These results indicated the existence of HGT events among the heavy metal resistance-related genes. Thus, HGT events might be an important way for $H$. zincidurans strain $\mathrm{B}^{\mathrm{T}}$ to acquire heavy metal resistant ability and to adapt to the heavy metal rich environment.

\section{Conclusion}

The draft genome sequence of the heavy metal resistant bacteria $H$. zincidurans strain $\mathrm{B}^{\mathrm{T}}$ isolated from the
South Atlantic Mid-Ocean Ridge provide an insight into the genomic basis of its heavy metal resistance ability. And HGT may play an important role in its adaption to the heavy metal rich environment. On the basis of analysis and characterization of genome, $H$. zincidurans strain $\mathrm{B}^{\mathrm{T}}$ might be resistant more kinds of heavy metal than we tested, such as $\mathrm{Hg}^{2+}, \mathrm{Cd}^{2+}, \mathrm{Pb}^{2+}, \mathrm{Ni}^{2+}$ and $\mathrm{Ag}^{+}$, etc. And it may have the potential for the bioremediation of multi-metal-contaminated environments. In addition, further analysis will be performed to confirm its resistant ability to other heavy metals and determine the mechanism of heavy metal resistance that we don't know yet. 
Table 6 Description of the genes related to heavy metal resistance

\begin{tabular}{|c|c|c|c|c|c|c|c|c|}
\hline \multirow[t]{2}{*}{ Protein id } & \multirow[t]{2}{*}{ Position } & \multirow[t]{2}{*}{ Size/aa } & \multirow[t]{2}{*}{ Strand } & \multirow[t]{2}{*}{ Predicted function } & \multicolumn{4}{|c|}{ Closest relatives } \\
\hline & & & & & Organism & Class & Identity & Accession no. \\
\hline HALZIN_54 & $48442-49500$ & 352 & + & RND family efflux transporter, MFP subunit & Idiomarina sediminum & Gammaproteobacteria & $44 \%$ & WP_026860724 \\
\hline HALZIN_399 & $433553-434005$ & 150 & + & $\begin{array}{l}\text { MerR family } \mathrm{Cd}(\mathrm{II}) / \mathrm{Pb}(\mathrm{II}) \text {-responsive } \\
\text { transcriptional regulator }\end{array}$ & Halomonas lutea & Gammaproteobacteria & $75 \%$ & WP_019019418 \\
\hline HALZIN_733 & $778272-780812$ & 846 & + & Heavy metal translocating P-type ATPase ZntA & Gracilimonas tropica & Sphingobacteriia & $59 \%$ & WP_020403952 \\
\hline HALZIN_916 & $977118-976882$ & 78 & - & Mercuric transport protein MerE & Burkholderia cepacia & Betaproteobacteria & $99 \%$ & YP_006965885 \\
\hline HALZIN_917 & 977480-977115 & 121 & - & Transcriptional regulator MerD & Pseudomonas putida & Gammaproteobacteria & $98 \%$ & WP_012806008 \\
\hline HALZIN_918 & 978239-977592 & 215 & - & Alkylmercury lyase MerB & Paraglaciecola polaris & Gammaproteobacteria & $84 \%$ & WP_007106069 \\
\hline HALZIN_919 & $979028-978390$ & 212 & - & Alkylmercury lyase MerB & Paraglaciecola polaris & Gammaproteobacteria & $94 \%$ & WP_007106069 \\
\hline HALZIN_920 & 979808-979179 & 209 & - & Alkylmercury lyase MerB & Paraglaciecola polaris & Gammaproteobacteria & $90 \%$ & WP_007106069 \\
\hline HALZIN_922 & $980118-980540$ & 140 & + & Transcriptional regulator MerR & Stenotrophomonas maltophilia & Gammaproteobacteria & $99 \%$ & WP_005413398 \\
\hline HALZIN_934 & $994405-993521$ & 294 & - & Magnesium and cobalt efflux protein CorC & Chromohalobacter salexigens & Gammaproteobacteria & $81 \%$ & WP_011507633 \\
\hline HALZIN_1240 & 1334217-1331998 & 739 & - & Heavy metal translocating P-type ATPase & Halomonas sp. & Gammaproteobacteria & $97 \%$ & WP_023004666 \\
\hline HALZIN_1392 & 1499237-1498659 & 192 & - & Superoxide dismutase & Halomonas smyrnensis & Gammaproteobacteria & $85 \%$ & WP_016854901 \\
\hline HALZIN_1411 & 1521826-1522995 & 389 & + & RND family efflux transporter, MFP subunit & Halomonas lutea & Gammaproteobacteria & $76 \%$ & WP_019017686 \\
\hline HALZIN_1413 & $1526330-1526785$ & 151 & + & Zinc uptake regulation protein ZUR & Halomonas lutea & Gammaproteobacteria & $82 \%$ & WP_019017691 \\
\hline HALZIN_2047 & $2179598-2182789$ & 1063 & + & RND family efflux transporter protein & Pseudoxanthomonas suwonensis & Gammaproteobacteria & $85 \%$ & WP_013535339 \\
\hline HALZIN_2196 & $2338252-2335574$ & 892 & - & Heavy metal translocating P-type ATPase ZntA & Halomonas lutea & Gammaproteobacteria & $65 \%$ & WP_019020337 \\
\hline HALZIN_2208 & $2355137-2351976$ & 1053 & - & RND family efflux transporter protein & Pseudomonas alcaligenes & Gammaproteobacteria & $58 \%$ & WP_021217164 \\
\hline HALZIN_2209 & $2356423-2351976$ & 428 & - & RND family efflux transporter, MFP subunit & Halomonas lutea & Gammaproteobacteria & $53 \%$ & WP_019020155 \\
\hline HALZIN_2260 & $2411989-2410787$ & 400 & - & Multicopper oxidase & Sphingopyxis baekryungensis & Alphaproteobacteria & $55 \%$ & WP_022673021 \\
\hline HALZIN_2261 & $2412630-2413034$ & 134 & + & Transcriptional regulator MerR & Halomonas lutea & Gammaproteobacteria & $90 \%$ & WP_019017365 \\
\hline HALZIN_2262 & 2413107-2415596 & 829 & + & Heavy metal translocating P-type ATPase & Halomonas lutea & Gammaproteobacteria & $92 \%$ & WP_019017357 \\
\hline HALZIN_2264 & $2416527-2416976$ & 149 & + & Transcriptional regulator MerR & Halomonas lutea & Gammaproteobacteria & $89 \%$ & WP_026300314 \\
\hline HALZIN_2268 & $2423176-2423622$ & 148 & + & CopG family transcriptional regulator & Halomonas lutea & Gammaproteobacteria & $80 \%$ & WP_019017364 \\
\hline HALZIN_2271 & $2424931-2425086$ & 51 & + & Copper resistance protein CopC & Hyphomonas neptunium & Alphaproteobacteria & $51 \%$ & WP_011646711 \\
\hline HALZIN_2272 & $2425115-2425978$ & 287 & + & Copper resistance protein CopD & Thialkalivibrio sp. & Gammaproteobacteria & $43 \%$ & WP_018881395 \\
\hline HALZIN_2469 & $2658088-2657690$ & 132 & - & Transcriptional regulator MerR & Halomonas lutea & Gammaproteobacteria & $90 \%$ & WP_019020805 \\
\hline HALZIN_2470 & $2658244-2658588$ & 114 & + & Mercuric transport protein MerT & Halomonas lutea & Gammaproteobacteria & $78 \%$ & WP_019020806 \\
\hline HALZIN_2471 & $2658620-2658925$ & 101 & + & Periplasmic mercury $(+2)$ binding protein MerP & Halomonas lutea & Gammaproteobacteria & $82 \%$ & WP_019020807 \\
\hline HALZIN_2472 & $2658988-2660622$ & 544 & + & Mercuric reductase, MerA family & Halomonas lutea & Gammaproteobacteria & $93 \%$ & WP_019020808 \\
\hline HALZIN_2675 & $2872087-2872584$ & 165 & + & Transcriptional regulator MerR & Halomonas sp. & Gammaproteobacteria & $66 \%$ & WP_023005510 \\
\hline HALZIN_3265 & $3489632-3489021$ & 203 & - & Superoxide dismutase & Halomonas lutea & Gammaproteobacteria & $74 \%$ & WP_019019731 \\
\hline
\end{tabular}




\section{Additional files}

Additional file 1: Table S1. Concentrations of heavy metals in deep-sea sediment collected from the South Atlantic Mid-Ocean Ridge (1) and the sediments from the Central Pacific seamount (2), offshore sediment (3) and continental crust (4).

Additional file 2: Table S2. Associated MIGS record.

\section{Abbreviations}

HGT: Horizontal gene transfer; RSCU: Relative synonymous codon usage.

\section{Competing interests}

The authors declare that they have no competing interests.

\section{Authors' contributions}

$\mathrm{YH}$ designed and performed experiments, analyzed data and wrote the paper; ZL performed experiments; HC analyzed genome data; CW analyzed data; XX designed the experiments and wrote the paper. All authors read and approved the final manuscript.

\section{Acknowledgements}

This work was supported by the China Ocean Mineral Resources R \& D Association (COMRA) Special Foundation (No. DY125-15-R-03); the National Natural Science Foundation of China (No. 41276173); the Zhejiang Provincial Natural Science Foundation of China (No. LQ13D060002) and the Scientific Research Fund of the Second Institute of Oceanography, SOA (No. JT1305).

\section{Author details}

${ }^{1}$ Laboratory of Marine Ecosystem and Biogeochemistry, Second Institute of Oceanography, State Oceanic Administration, Hangzhou, P. R. China. ${ }^{2}$ College of Life Sciences, Zhejiang University, Hangzhou, P. R. China.

Received: 9 July 2014 Accepted: 23 November 2014

Published: 29 December 2014

\section{References}

1. Valls M, de Lorenzo V. Exploiting the genetic and biochemical capacities of bacteria for the remediation of heavy metal pollution. FEMS Microbiol Rev. 2002; 26(4):327-38.

2. Nies DH. Microbial heavy-metal resistance. Appl Microbiol Biotechnol. 1999; 51(6):730-50.

3. Özdemir S, Kilinc E, Poli A, Nicolaus B, Güven K. Cd, Cu, Ni, Mn and Zn resistance and bioaccumulation by thermophilic bacteria. Geobacillus toebii subsp decanicus and Geobacillus thermoleovorans subsp stromboliensis World J Microbiol Biotechnol. 2012; 28(1):155-63.

4. Teitzel GM, Parsek MR. Heavy metal resistance of biofilm and planktonic Pseudomonas aeruginosa. Appl Environ Microbiol. 2003; 69(4):2313-20.

5. Xu L, Xu X-W, Meng F-X, Huo Y-Y, Oren A, Yang J-Y, Wang C-S. Halomonas zincidurans sp. nov., a heavy-metal-tolerant bacterium isolated from the deep-sea environment. Int J Syst Evol Microbiol. 2013; 63(Pt 11):4230-36.

6. Arahal DR, Ventosa A. The family Halomonadaceae. In: Dworkin M, Falkow S, Rosenberg E, Schleifer KH, Stackebrandt E, editors. The Prokaryotes: a Handbook on the Biology of Bacteria, Volume 6. 3rd ed. New York: Springer; 2006: p. 811.

7. Nieto JJ, Fernandez-Castillo R, Marquez MC, Ventosa A, Quesada E, Ruiz-Berraquero F. Survey of metal tolerance in moderately halophilic eubacteria. Appl Environ Microbiol. 1989; 55(9):2385-90.

8. Feely RA, Geiselman TL, Baker ET, Massoth GJ, Hammond SR. Distribution and composition of hydrothermal plume particles from the ASHES Vent Field at Axial Volcano, Juan de Fuca Ridge. J Geophys Res: Solid Earth. 1990; 95(B8):12855-73.

9. Huo Y, Cheng H, Anton FP, Wang C, Jiang X, Pan J, Wu M, Xu X. Ecological functions of uncultured microorganisms in the cobalt-rich ferromanganese crust of a seamount in the central Pacific are elucidated by fosmid sequencing. Acta Oceanologica Sinica. 2014. in press.

10. Zhao Q. Ocean Geochemistry. Beijing: The Geological Publishing House; 1988.

11. Hans WK. The composition of the continental crust. Geochim Cosmochim Acta. 1995; 59(7):1217-32.
12. Field D, Garrity G, Gray T, Morrison N, Selengut J, Sterk P, Tatusova T, Thomson N, Allen MJ, Angiuoli SV, Ashburner M, Axelrod N, Baldauf S, Ballard S, Boore J, Cochrane G, Cole J, Dawyndt P, De Vos P, dePamphilis C, Edwards R, Faruque N, Feldman R, Gilbert J, Gilna P, Glöckner FO, Goldstein P, Guralnick R, Haft D, Hancock D, et al. The minimum information about a genome sequence (MIGS) specification. Nat Biotechnol. 2008; 26(5):541-7.

13. Woese $C R$, Kandler $\mathrm{O}$, Wheelis ML. Towards a natural system of organisms: proposal for the domains Archaea, Bacteria, and Eucarya. Proc Natl Acad Sci U S A. 1990; 87(12):4576-9.

14. Garrity GM, Bell JA, Lilburn T. Phylum XIV. Proteobacteria phyl. nov. In: Garrity GM, Brenner DJ, Krieg NR, Staley JT, editors. Bergey's Manual of Systematic Bacteriology, Volume 2, Part B. 2nd ed. New York: Springer; 2005: p. 1.

15. Validation of publication of new names and new combinations previously effectively published outside the IJSEM. Int J Syst Evol Microbiol. 2005; 55(6):2235-38.

16. Garrity GM, Bell JA, Lilburn T. Class III. Gammaproteobacteria class. nov. In: Garrity GM, Brenner DJ, Krieg NR, Staley JT, editors. Bergey's Manual of Systematic Bacteriology, Volume 2, Part B. 2nd ed. New York: Springer; 2005: p. 1.

17. Garrity GM, Bell JA, Lilburn T. Order VIII. Oceanospirillales ord. nov. In: Brenner DJ, Krieg NR, Staley JT, Garrity GM, editors. Bergey's Manual of Systematic Bacteriology, Volume 2. 2nd ed. Springer, New York: Part B; 2005: p. 270.

18. Franzmann PD, Wehmeyer U, Stackebrandt E. Halomonadaceae fam. nov., a new family of the class Proteobacteria to accommodate the genera Halomonas and Deleya. Syst Appl Microbiol. 1988; 11(1):16-9.

19. Ntougias S, Zervakis Gl, Fasseas C. Halotalea alkalilenta gen. nov., sp. nov., a novel osmotolerant and alkalitolerant bacterium from alkaline olive mill wastes, and emended description of the family Halomonadaceae Franzmann et al. 1989, emend. Dobson and Franzmann 1996. Int J Syst Evol Microbiol. 2007; 57(9):1975-83.

20. Ben Ali Gam Z, Abdelkafi S, Casalot L, Tholozan JL, Oueslati R, Labat M. Modicisalibacter tunisiensis gen. nov., sp. nov., an aerobic, moderately halophilic bacterium isolated from an oilfield-water injection sample, and emended description of the family Halomonadaceae Franzmann et al. 1989 emend Dobson and Franzmann 1996 emend. Ntougias et al. 2007. Int J Syst Evol Microbiol. 2007; 57(10):2307-13.

21. NOTES. Validation of the publication of new names and new combinations previously effectively published outside the IJSB: List No. 29+. Int J Syst Bacteriol. 1989; 39(2):205-06.

22. Dobson SJ, Franzmann PD. Unification of the genera Deleya (Baumann et al. 1983), Halomonas (Vreeland et al. 1980), and Halovibrio (Fendrich 1988) and the species Paracoccus halodenitrificans (Robinson and Gibbons 1952) into a single genus, Halomonas, and placement of the genus Zymobacter in the Family Halomonadaceae. Int J Syst Bacteriol. 1996; 46(2):550-58.

23. Vreeland RH, Litchfield CD, Martin EL, Elliot E. Halomonas elongata, a new genus and species of extremely salt-tolerant bacteria. Int I Syst Bacteriol. 1980; 30(2):485-95.

24. Mellado E, Moore ERB, Nieto JJ, Ventosa A. Phylogenetic inferences and taxonomic consequences of $16 \mathrm{~S}$ ribosomal DNA sequence comparison of Chromohalobacter marismortui, Volcaniella eurihalina, and Deleya salina and reclassification of $V$. eurihalina as Halomonas eurihalina comb. nov. Int J Syst Bacteriol. 1995; 45(4):712-16.

25. Ashburner M, Ball CA, Blake JA, Botstein D, Butler H, Cherry JM, Davis AP, Dolinski K, Dwight SS, Eppig JT, Harris MA, Hill DP, Issel-Tarver L, Kasarskis A, Lewis S, Matese JC, Richardson JE, Ringwald M, Rubin GM, Sherlock G. Gene ontology: tool for the unification of biology. The Gene Ontology Consortium. Nat Genet. 2000; 25(1):25-9.

26. Thompson JD, Higgins DG, Gibson TJ. CLUSTAL W: improving the sensitivity of progressive multiple sequence alignment through sequence weighting, position-specific gap penalties and weight matrix choice. Nucleic Acids Res. 1994; 22(22):4673-80.

27. Saitou N, Nei M. The neighbor-joining method: a new method for reconstructing phylogenetic trees. Mol Biol Evol. 1987; 4(4):406-25.

28. Kimura M. A simple method for estimating evolutionary rates of base substitutions through comparative studies of nucleotide sequences. J Mol Evol. 1980; 16(2):111-20.

29. Tamura K, Peterson D, Peterson N, Stecher G, Nei M, Kumar S. MEGA5: molecular evolutionary genetics analysis using maximum likelihood, evolutionary distance, and maximum parsimony methods. Mol Biol Evol. 2011; 28(10):2731-39. 
30. Li R, Zhu H, Ruan J, Qian W, Fang X, Shi Z, Li Y, Li S, Shan G, Kristiansen K. De novo assembly of human genomes with massively parallel short read sequencing. Genome Res. 2010; 20(2):265-72.

31. Delcher AL, Bratke KA, Powers EC, Salzberg SL. Identifying bacterial genes and endosymbiont DNA with Glimmer. Bioinformatics. 2007; 23(6):673-79

32. Marmur J. A procedure for the isolation of deoxyribonucleic acid from microorganisms. J Mol Biol. 1961; 3(2):208-18.

33. Bentley DR, Balasubramanian S, Swerdlow HP, Smith GP, Milton J, Brown CG, Hall KP, Evers DJ, Barnes CL, Bignell HR, Boutell JM, Bryant J, Carter RJ, Cheetham RK, Cox A, Ellis DJ, Flatbush MR, Gormley NA, Humphray SJ, Inving $\sqcup$, Karbelashvili MS, Kirk SM, Li H, Liu X, Maisinger KS, Murray L, Obradovic B, Ost T, Parkinson ML, Pratt MR, et al. Accurate whole human genome sequencing using reversible terminator chemistry. Nature. 2008; 456(7218):53-9.

34. Lowe TM, Eddy SR. tRNAscan-SE: a program for improved detection of transfer RNA genes in genomic sequence. Nucleic Acids Res. 1997; 25(5):955-64.

35. Lagesen K, Hallin P, Rodland EA, Staerfeldt HH, Rognes T, Ussery DW. RNAmmer: consistent and rapid annotation of ribosomal RNA genes. Nucleic Acids Res. 2007; 35(9):3100-08.

36. Bairoch A, Boeckmann B. The SWISS-PROT protein sequence data bank. Nucleic Acids Res. 1992; 20(Suppl):2019-22.

37. Tatusov RL, Galperin MY, Natale DA, Koonin EV. The COG database: a tool for genome-scale analysis of protein functions and evolution. Nucleic Acids Res. 2000; 28(1):33-6.

38. Aziz RK, Bartels D, Best AA, DeJongh M, Disz T, Edwards RA, Formsma K, Gerdes S, Glass EM, Kubal M, Meyer F, Olsen GJ, Olson R, Osterman AL, Overbeek RA, McNeil LK, Paarmann D, Paczian T, Parrello B, Pusch GD, Reich C, Stevens R, Vassieva O, Vonstein V, Wilke A, Zagnitko O: The RAST Server: rapid annotations using subsystems technology. BMC Genomics. 2008; 9:75

39. Moriya Y, Itoh M, Okuda S, Yoshizawa AC, Kanehisa M. KAAS: an automatic genome annotation and pathway reconstruction server. Nucleic acids res. 2007; 35(suppl 2):W182-5.

40. Kanehisa M, Goto S, Kawashima S, Okuno Y, Hattori M. The KEGG resource for deciphering the genome. Nucleic Acids Res. 2004; 32(Database issue):D277-80

41. Krogh A, Larsson B, von Heijne G, Sonnhammer ELL. Predicting transmembrane protein topology with a hidden markov model: application to complete genomes. J Mol Biol. 2001; 305(3):567-80.

42. Dyrløv Bendtsen J, Nielsen H, von Heijne G, Brunak S. Improved prediction of signal peptides: SignalP 3.0. J Mol Biol. 2004; 340(4):783-95.

43. McCall KA, $\mathrm{C}-\mathrm{CH}$, Fierke CA. Function and mechanism of zinc metalloenzymes. J Nutr. 2000; 130(5):1437S-46S.

44. Choudhury R, Srivastava S. Zinc resistance mechanisms in bacteria. Cur Sci. 2001; 81(7):768-75.

45. Blencowe DK, Morby AP. Zn (II) metabolism in prokaryotes. FEMS Microbiol Rev. 2003; 27(2-3):291-311.

46. Rensing C, Sun Y, Mitra B, Rosen BP. Pb(II)-translocating P-type ATPases. J Biol Chem. 1998; 273(49):32614-17.

47. Rensing C, Mitra B, Rosen BP. The zntA gene of Escherichia coli encodes a Zn(II)-translocating P-type ATPase. Proc Natl Acad Sci U S A. 1997; 94(26):14326-31.

48. Brown NL, Stoyanov JV, Kidd SP, Hobman JL. The MerR family of transcriptional regulators. FEMS Microbiol Rev. 2003; 27(2-3):145-63.

49. Brocklehurst KR, Hobman JL, Lawley B, Blank L, Marshall SJ, Brown NL, Morby AP. ZntR is a Zn(II)-responsive MerR-like transcriptional regulator of zntA in Escherichia coli. Mol Microbiol. 1999; 31(3):893-902.

50. Hantke K. Bacterial zinc uptake and regulators. Curr Opin Microbiol. 2005: 8(2):196-202.

51. Sone Y, Pan-Hou H, Nakamura R, Sakabe K, Kiyono M. Roles played by MerE and MerT in the transport of inorganic and organic mercury compounds in Gram-negative bacteria. J Health Sci. 2010; 56(1):123-27.

52. Pitts KE, Summers $\mathrm{AO}$. The roles of thiols in the bacterial organomercurial lyase (MerB). Biochemistry. 2002; 41(32):10287-96.

53. Felske A, Fehr W, Pauling B, von Canstein H, Wagner-Dobler I. Functional profiling of mercuric reductase (mer A) genes in biofilm communities of a technical scale biocatalyzer. BMC Microbiol. 2003; 3(1):22

doi:10.1186/1944-3277-9-30

Cite this article as: Huo et al: High quality draft genome sequence of the heavy metal resistant bacterium Halomonas zincidurans type strain B6 ${ }^{\top}$. Standards in Genomic Sciences 2014 9:30.

\section{Submit your next manuscript to BioMed Central and take full advantage of:}

- Convenient online submission

- Thorough peer review

- No space constraints or color figure charges

- Immediate publication on acceptance

- Inclusion in PubMed, CAS, Scopus and Google Scholar

- Research which is freely available for redistribution 